\title{
CYP2C9*16 Allele
}

National Cancer Institute

\section{Source}

National Cancer Institute. CYP2C9*16 Allele. NCI Thesaurus. Code C46018.

Human CYP2C9*16 allele is located within 10q24 and is approximately $33 \mathrm{~kb}$ in length. This allele, a variant form of the CYP2C9 wild-type allele, encodes cytochrome P450 2C9*16 protein. The CYP2C9*16 allele exhibits a clinically-relevant SNP (c.895A>G) that results in a T299A coding change. This alteration in protein sequence decreases the in vivo enzymatic activity of the cytochrome P450 2C9*16 protein. 